\title{
Pengaruh aplikasi color detector for blind on based android (coda) terhadap pengenalan warna bagi penyandang tunanetra di Yogyakarta
}

\author{
Sayidatul Maslahah, Tin Suharmini \\ Jurusan Pendidikan Luar Biasa FIP UNY. Jalan Colombo No.1, Yogyakarta, 55281, Indonesia. \\ * Corresponding Author. E-mail: sayidatulmaslahah@gmail.com
}

\begin{abstract}
Abstrak: Tujuan dalam penelitian ini adalah untuk menguji pengaruh Color Detector For Blind Based on Android (CODA) terhadap pengenalan warna bagi penyandang tunanetra kelas VIII di MTS LB A Yaketunis Yogyakarta. Penelitian ini menggunakan pendekatan kuantitatif dengan jenis penelitian kuasi eksperimen. Desain penelitian One Group Pre Test- Post Test Design. Analisis data yang digunakan adalah analisis statistic deskriptif dan uji nonparametrik. Kemudian dianalisis dengan statistic deskriptif dan dilanjutkan uji nonparametrik tes Wilcoxon. Hasil penelitian menunjukkan bahwa ada pengaruh yang sangat signifikan aplikasi CODA terhadap pengenalan warna bagi penyandang tunanetra kelas VIII di MTs LB A Yaketunis Yogyakarta. Perolehan skor pre-test menunjukkan rata-rata skor sebesar 27,2 dengan presentase 45,3\%. Skor post-test ratarata sebesar 44,4 dengan prosentase $73,96 \%$ sehingga rata-rata skor perubahan kelima subjek sebesar 17,2 dengan presentase 28,66\%. Hasil uji statistic nonparametric tes Wilcoxon memperoleh $T$ hitung $\leq T$ table dengan harga $T$ hitung 0 dan harga $T$ table 0 dengan taraf signifikansi yang digunakan $\alpha=0,01$ maka Ha diterima dan Ho ditolak.
\end{abstract}

Kata kunci: Color Detector for Blind Based on Android (CODA) pengenalan Warna, Penyandang Tunanetra.

\section{Effect of color detector for blind on based android (coda) application on color recognition for blind people in Yogyakarta}

\begin{abstract}
This study aimed to examine the influence of Color Detector For Blind Based on Android (CODA) towards blind people at 8th grade in MTS LB A Yaketunis Yogyakarta to identify colors. This research used quantitative approach. The method used is quasi experiment with One Group Pre Test- Post Test Design for its experiment design. The data of this research was analyzed by statistic descriptive analysis and non parametic experiment. Data result from statistic descriptive analysis displayed in a form of table and chart continued Wilcoxon test non parametic experiment. The result shows that Color Detector for Blind Based on Android (CODA) application has significant influence towards blind people at 8th grade in MTS LB A Yaketunis Yogyakarta to identify colors. The result of the pre-test score shows that the five participants on average get a score of 27.2 with a percentage of $45.3 \%$. The post-test score of the five participants on average get a score of 44.4 with a percentage of $73.96 \%$. Thus, the average score changing is 17.2 with a percentage of $28.66 \%$. Wilcoxon test non parametic experiment shows $\mathrm{T}$ arithmetic $\leq \mathrm{T}$ table with value $\mathrm{T}$ arithmetic 0 and price $\mathrm{T}$ table 0 with significance level used $\alpha=0,01$ then Ha is accepted and Ho is rejected.
\end{abstract}

Keywords: Color Detector for Blind Based on Android (CODA) colors identify, blind people.

\section{PENDAHULUAN}

Berdasarkan seluruh indera yang dimiliki oleh manusia, penglihatan adalah dria yang memperoleh informasi paling banyak, diperkirakan 85 \% fungsi indera penglihatan (Rudiyati, 2002: 74). Salah satu dampak yang ditimbulkan oleh kehilangan dria penglihatan adalah ketidakmampuan dalam mengenali warna. Oleh sebab itu, sebagai gantinya maka penyandang tunanetra harus berusaha menggunakan sisa dria yang lainnya yang masih berfungsi seperti dria pendengaran, dria tactual, dria penciuman, dan lain sebagainya untuk memperoleh informasi tentang dunia sekitarnya. (Rudiyati, 2002: 77).

Menurut Lowenfeld (1973 dalam Hallahan, dkk., 2009: 405) ketunanetraan dapat mengakibatkan tiga macam keterbatasan, yakni: 1) keterbatasan dalam memahami konsep dan pemaknaan, 2) keterbatasan dalam kemampuan untuk berpindah tempat, dan 3) keterbatasan untuk mengontrol dan berinteraksi dengan lingkungan. Sebagai upaya penanganan dari hambatan yang 


\section{J PK (J urnal Pendidikan Khusus), 13 (1), 2018 - 36}

Sayidatul Maslahah, Tin Suharmini

dialami, seringkali mereka didampingi oleh orang awas. Sedangkan untuk memahami konsep berbagai informasi, seorang tunanetra terpaksa melakukan deskripsi verbal dari orang lain.

Sedangkan untuk memahami konsep berbagai informasi, seorang tunanetra terpaksa melakukan deskripsi verbal dari orang lain, salah satunya dalam pemerolehan informasi tentang warna. Warna adalah suatu kecenderungan yang dihasilkan ketika spektrum tertentu yang ada di dalam energi cahaya mengenai suatu benda (Nurdian, 2009: 12). Menurut Darmaprawira, Sulasmi (2001: 28) sensasi warna akan terjadi bila ada cahaya.

Manfaat dari warna dalam kehidupan sehari-hari salah satunya untuk mengidentifikasi suatu benda. Hal tersebut sesuai dengan yang dirasakan oleh penyandang tunanetra bahwa pengetahuan tentang warna pada tunanetra terutrama pada penggunaan pakaian masih sangat minim. Contoh tersebut hanya sebagian kecil dari permasalahan yang ditimbulkan akibat ketidakmampuan melihat warna. Dampak lain yang ditimbulkan biasanya ketika berbelanja, penyandang tunanetra tidak tahu barang mana yang harus dibeli sesuai dengan yang dibutuhkan. Mereka seringkali keliru dalam memilih barang yang akan dibelinya. Melihat pentingnya kemampuan dalam membedakan warna bagi tunanetra, maka dibutuhkan suatu alat yang dapat mendeteksi warna suatu benda.

Selain itu, hal ini juga dirasakan oleh penyandang Tunanetra di MTS LB Yaketunis sebagian besar mengalami ketunanetraan sejak lahir dan belum adanya pengenalan warna secara intensif. Upaya yang dilakukan oleh pijhak guru masih sebatas kepada penyampaian secara lisan dan hanya menyebut nama warna saja. Sehingga penyandnag tuannetra yang berada di MTs LB A Yaketunis masih mengalami kebingungan dan selalu meminta bantuan irang awas dalam menentukan warna. Terutama Penyandang Tunanetra kelas VIII yang berada di MTs LB A Yaketunis.

Di sisi lain, jumlah pengguna alat teknologi, khususnya smartphone di Indonesia dari tahun ke tahun semakin meningkat. Android memiliki fitur khusus untuk lebih merambah ke semua kalangan. Salah satu fitur yang disematkan pada Android seri Jelly Bean saat ini adalah fitur TalkBack. Pengertian aplikasi (Nugroho, 2009: 1) adalah program yang ditulisuntuk melaksanakan tugas khusus dari pengguna. Aplikasi ini memiliki fitur yang di rancang khusus untuk pengguna android yang memiliki keterbatasan pengelihatan. Fungsi utama aplikasi ini adalah mengucapkan semua yang dilakukan di ponsel android. Aplikasi TalkBack ini, dibuat untuk mempermudah para penderita kelainan penglihatan atau tunanetra agar dapat menggunakan smartphone android yang kebanyakan memiliki layar sentuh (Priyadi, TT).

Kesulitan dalam mengenali warna bagi penyandang tunanetra tersebut dapat diatasi dengan aplikasi Color Detector for Blind (CODA) Based Android. Aplikasi CODA ini juga sudah disesuaikan dengan kebutuhan pengguna penyandang tunanetra yaitu dengan memperhatikan aspek memanfaatkan dria-non visual yang bisa digunakan oleh penyandang tunanetra. Color Detector for Blind (CODA) Based Android merupakan alat bantu pendeteksi warna bagi tunanetra berbasis android. Aplikasi ini memberikan informasi berupa suara yang menjelaskan nama dan deskripsi warna. Peneliti mengembangkan dengan bahasa pengoperasian khusus anak tunanetra seperti pada aplikasi Talkback. Output yang dihasilkan berupa deteksi warna berbasis audio. Alat tersebut dilengkapi dengan vitur penjelasan warna suatu benda yang biasa ditemukan dalam kehidupan sehari-hari. Pengembangan alat tersebut bertujuan untuk memudahkan tunanetra dalam mendeteksi warna suatu benda. Tujuan utamanya yakni membantu mengenal warna pada buah-buahan, warna uang, dan pakaian atau seragam penyandang tuananetra dalam beraktivitas sehari-hari (Maslahah, 2017).

Berdasarkan permasalahan yang telah diungkapkan di atas, maka perlu adanya aplikasi pada Android untuk mendeteksi warna untuk anak tunanetra. Penelitian mengenai aplikasi CODA sudah dilakukan berdasarkan LKTI Pekan Ilmiah Fisika tahun 2016 menjadi juara 1 dan didanai oleh KEMENRISTEK DIKTI tahun 2017 pada program PKM yaitu PKM-KC. Sehingga diperlukan penelitian lanjut menganai aplikasi CODA (Maslahah, 2017). Hal yang mendorong dilaksanakan penelitian ini adalah belum pernah diadakan penelitian yang menguji pengaruh aplikasi Color Detector for Blind (CODA) Based Android. Maka dari itu skripsi ini meneliti tentang pengaruh aplikasi Color Detector for Blind Based on Android (CODA) terhadap pengenalan warna bagi penyandang tunanetra di MTs LB A Yaketunis Yogyakarta.

Adapun tujuan dalam penelitian ini adalah untuk menguji pengaruh Color Detector For Blind Based on Android (CODA) berpengaruh terhadap pengenalan warna bagi penyandang tunanetra kelas VIII di MTS LB A Yaketunis Yogyakarta.. 


\section{J PK (J urnal Pendidikan Khusus), 13 (1), 2018 - 37}

Sayidatul Maslahah, Tin Suharmini

\section{METODE}

\section{Jenis Penelitian}

Jenis penelitian yang digunakan dalam penelitian yaitu kuasi eksperimen dengan pendekatan kuantitatif. Desain penelitian yang digunakan dalam penelitian yaitu One Group Pre Test - Post Test Design (Sugiyono, 2007: 111). Pengukuran kemampuan subjek dilakukan sebelum dan sesudah intervensi melalui perbedaan hasil pengukuran awal (O1) dan pengukuran hasil (O2). Dan subjek diberikan intervensi yang dilakukan di kelas. Adapun desain penelitian tersebut dapat digambarkan sebagai berikut:

\section{Desain One Group Pre Test - Post Test $01 \times 02$}

Gambar 1. Desain Penelitian

\section{Waktu dan Tempat Penelitian}

Penelitian ini dilakukan pada tanggal 13 Februari dampai 13 Maret 2018. Penelitian ini dilakukan di MTs LB A Yaketunis Yogyakarta yang beralamat di jalan Parangtritis nomer 46, Danunegaran, Mantrijeron, Yogyakarta.

\section{Subjek Penelitian}

Adapun subjek penelitian dalam penelitian ini adalah penyandang tunanetra yang berada di kelas VIII MTs LB A Yaketunis.

\section{Prosedur}

Sesuai desain penelitian yaitu pretest - perlakuan - post test, pelaksanaan perlakuan penggunaan aplikasi CODA yaitu setelah melakukan pre test atau kemampuan awal penyandang mengenai pengenalan warna, kemudian melakukan post test untuk mengukur kemampuan hasil setelah adanya perlakuan aplikasi CODA. Perlakuan dalam penelitian ini akan dilakukan 5 kali selama 2 minggu dengan menggunakan aplikasi CODA. Prosedur perlakuan yang akan dilakukan antara lain:

1. Tahap Awal

a. Tahap Persiapan (menentukan subjek, menyusun tes pre-test dan post-test.

b. Tahap pre-test

2. Tahap Perlakuan

a. Kegiatan awal (menyiapkan aplikasi CODA, menginstal aplikasi $C O D A$, menyiapkan ruangan.

b. Kegiatan Inti (memperhatikan cara penggunaan aplikasi $C O D A$, mencoba meletakkan kamera kepada benda, mendengarkan output audio dari aplikasi CODA, anak untuk mencoba mengenali warna ke berbagai benda yaitu buku, buah, baju, dan seragam, mengajak anak untuk mendiskripsikan masing-masing makna dari warna, diajak untuk mengenali pakaian yang digunakan apakah sudah matching atau belum, mnemadupadankan warna baju dan jilbab, kemudian mengenalkan warna primer dan sekunder yang lainnya.

c. Tahap Akhir Post-test.

\section{Uji Validitas Instrumen}

Penelitian ini menggunakan uji validitas instrument dengan cara pengujian face validaty. Pengujian validitas dilakukan dengan menggunakan pendapat dari ahli atau expert judgement. Aspek yang diajukan yakni kesesuaian isi dan kejelasan instrument dengan tujuan penelitian.

\section{Analisis Data}

Analisis data yang digunakan adalah statistic inferensial dengan jenis statistik non-parametrik yang menggunakan tes wilcoxon dengan melihat selisih skor antara hasil skor pre-test dan post-test serta dilengkapi dengan statistik deskriptif untuk memperkuat analisis data.

Jumlah skor tertinggi kemampuan mengenali warna adalah 60, sedangkan yang terendah adalah 15. Setelah kedua skor dijumlahkan dan menjadi skor kemampuan mengenali warna, selanjutnya skor dipresentasikan dalam bentuk prosentase. Rumus yang digunakan untuk mempresentasikan dalam bentuk presentase (dalam M. Ngalim Purwanto, 2006:102) adalah sebagai berikut: 
J PK (J urnal Pendidikan Khusus), 13 (1), 2018 - 38

Sayidatul Maslahah, Tin Suharmini

Keterangan:

$$
N P=\frac{R}{S M} x 100
$$

NP : Nilai persen yang dicari atau diharapkan

$\mathrm{R} \quad$ : Skor kemampuan mengenali warna yang diperoleh penyandang Tunanetra

SM : Skor kemampuan mengenali warna maksimal

100 : Bilangan tetap

\section{HASIL DAN PEMBAHASAN}

\section{Pre-test}

Jumlah tes yang digunakan pada pre-test adalah 15 soal penjabaran dari kognitif, afektif, dan psikomotor. Gambaran awal kemampuan mengenal warna pada penyandang Tunanetra kelas VIII di MTs LB A Yaketunis adalah sebagai berikut:

Tabel 1. Perolehan skor pre-test kemampuan mengenal warna penyandang Tunanetra.

\begin{tabular}{clccc}
\multirow{2}{*}{ No } & \multirow{2}{*}{ Subjek } & \multicolumn{2}{c}{ Kemampuan Mengenal Warna } & \multirow{2}{*}{ Presentase } \\
\cline { 3 - 4 } & & Skor Maksimal & Skor yang diperoleh & \\
\hline 1. & AAP & 60 & 32 & $53,3 \%$ \\
2. & AN & 60 & 28 & $46,6 \%$ \\
3. & B & 60 & 26 & $43,3 \%$ \\
4. & H & 60 & 24 & $40 \%$ \\
5. & L & 60 & 26 & $43.3 \%$ \\
\hline
\end{tabular}

Berdasarkan data yang disajikan dalam tabel 1, menunjukkan bahwa skor pre-test masih rendah jika dibandingkan skor maksimal yaitu 60 dengan presentase $100 \%$. Perolehan skor tertinggi yaitu 32 dengan presentase 53,3 \% dan terendah 24 dengan presentase $40 \%$. Hal ini dikarenakan kemampuan mengenal warna penyandang tunanetra di kelas VIII MTs LB A Yaketunis masih lemah. Perolehan skor tertinggi diperoleh oleh AAP, hal ini dipengaruhi oleh kemampuan AAP dalam konsentrasi dan factor kognitif yang cerdas menurut penuturan guru di MTs LB A yaketunis sehingga AAP berusaha mengenal warna dengan maksimal. Sedangkan perolehan skor terendah adalah $\mathrm{H}$. Hal ini dipengaruhi oleh kemampuan mengenal warna yang sangat lemah dan masih banyak yang belum banyak pengalaman visual yang diperoleh.

Skor pre-test kemampuan mengenal warna penyandang Tunanetra di kelas VIII MTs LB A Yaketunis dapat lebih dijelaskan melalui histogram berikut:

\section{Pre-test}

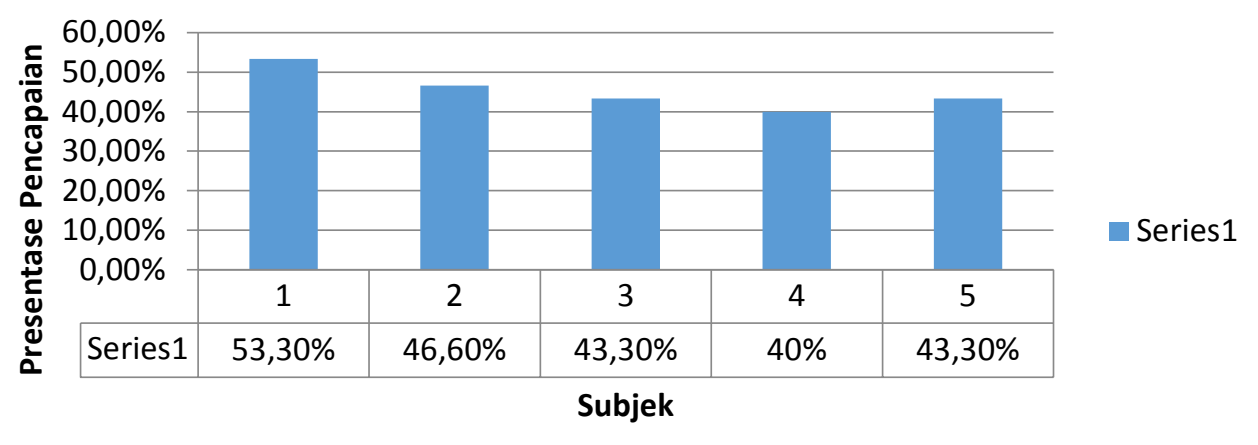

Gambar 2. Histogram hasil perolehan skor pre-test mengenal warna bagi penyandang tunanetra di MTs LB A Yaketunis

Keterangan:

$\begin{array}{ll}1= & \text { adalah subjek AAP } \\ 2= & \text { adalah subjek AN } \\ 3= & \text { adalah subjek B } \\ 4= & \text { adalah subjek H } \\ 5= & \text { adalah subjek L }\end{array}$


J PK (J urnal Pendidikan Khusus), 13 (1), 2018 - 39

Sayidatul Maslahah, Tin Suharmini

Tabel 2. Hasil perhitungan masing-masing aspek dalam pre-test

\begin{tabular}{clccc}
\hline \multirow{2}{*}{ No } & \multirow{2}{*}{ Subjek } & \multicolumn{3}{c}{ Aspek } \\
\cline { 3 - 5 } & & Kognitif & Afektif & Psikomotor \\
\hline 1. & AAP & $60 \%$ & $55 \%$ & $45 \%$ \\
2. & AN & $60 \%$ & $50 \%$ & $30 \%$ \\
3. & B & $55 \%$ & $45 \%$ & $30 \%$ \\
4. & H & $55 \%$ & $40 \%$ & $25 \%$ \\
5. & L & $60 \%$ & $45 \%$ & $25 \%$ \\
\hline
\end{tabular}

Berdasarkan data diatas maka dapat ditarik kesimpulan pada saat melakukan pre-test didapatkan hasil bahwa aspek yang paling tinggi yaitu aspek kognitif dengan rata-rata skor 11,6 dan persentase $58 \%$. Sedangkan aspek yang terendah adalah aspek psikomotor dengan skor 6,2 dan persentase $31 \%$.

Post test

Post-test dilakukan dengan cara tes lisan dan dengan menggunakan instrument buah-buahan, uang, dan baju/ seragam. Setiap soal memiliki skor tertinggi 4 dan skor terendah 1 . Hasil dari skor kemampuan mengenal warna dari aspek kognitif, afektif, dan psikomotor sehingga menghasilkan skor total pre-test kemampuan mengenal warna. Pengujian post-test dilakukan tanggal 23-24 Februari 2018. Tempat pengujian berada di ruang perpustakaan MTs LB A Yaketunis.

Tabel 3. Perolehan skor post-test kemampuan mengenal warna penyandang Tunanetra.

\begin{tabular}{clccc}
\hline \multirow{2}{*}{ No } & \multirow{2}{*}{ Subjek } & \multicolumn{2}{c}{ Kemampuan Mengenal Warna } & \multirow{2}{*}{ Presentase } \\
\cline { 3 - 4 } & Skor Maksimal & Skor yang diperoleh & \\
\hline 1. & AAP & 60 & 50 & $83,3 \%$ \\
2. & AN & 60 & 44 & $73,3 \%$ \\
3. & B & 60 & 42 & $70,0 \%$ \\
4. & H & 60 & 40 & $66,6 \%$ \\
5. & L & 60 & 46 & $76,6 \%$ \\
\hline
\end{tabular}

Dari data yang disajikan dalam table 2, menunjukkan bahwa skor post-test masih rendah jika dibandingkan skor maksimal yaitu 60 dengan presentase $100 \%$. Perolehan skor tertinggi yaitu 50 dengan presentase 83,3 \% dan terendah 40 dengan presentase 66,6 \%.

Skor post-test kemampuan mengenal warna penyendang Tunanetra di kelas VIII MTs LB A Yaketunis dapat lebih dijelaskan melalui histogram berikut:

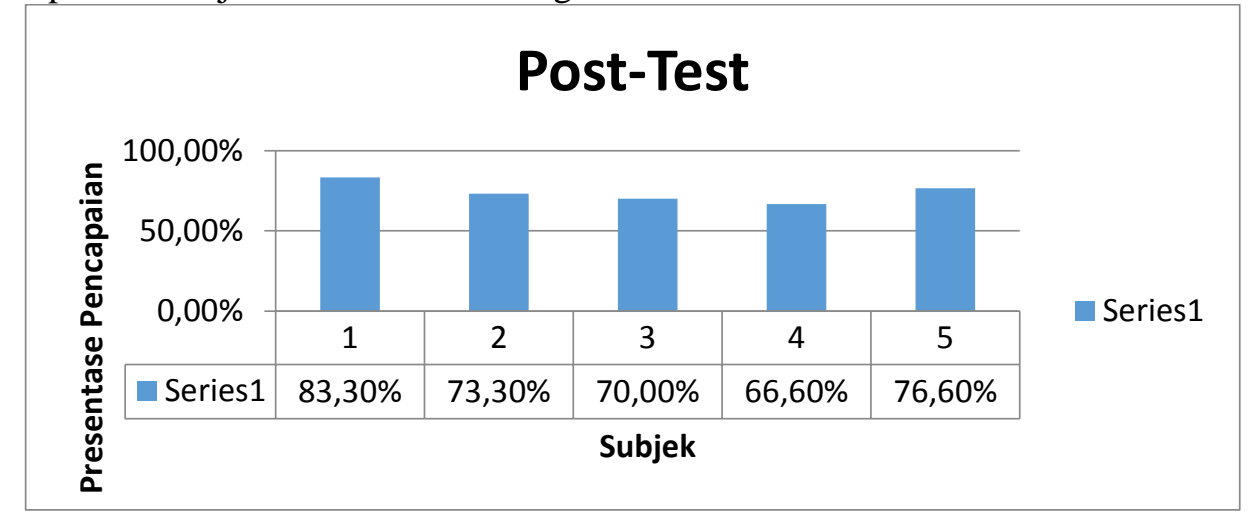

Gambar 3. Histogram hasil perolehan skor post-test mengenal warna bagi penyandang tunanetra di MTs LB A Yaketunis.

Keterangan:

$$
\begin{array}{ll}
1= & \text { adalah subjek AAP } \\
2= & \text { adalah subjek AN } \\
3= & \text { adalah subjek B } \\
4= & \text { adalah subjek H } \\
5= & \text { adalah subjek L }
\end{array}
$$


Dari data yang disajikan dalam histogram, menunjukkan bahwa skor post-test masih rendah jika dibandingkan skor maksimal yaitu 60 dengan presentase $100 \%$. Perolehan skor tertinggi yaitu 50 dengan presentase 83,3\% dan terendah 40 dengan presentase 66,6 \%.

Tabel 4. Hasil perhitungan masing-masing aspek dalam post-test

\begin{tabular}{ccccc}
\hline \multirow{2}{*}{ No } & \multirow{2}{*}{ Subjek } & \multicolumn{3}{c}{ Aspek } \\
\cline { 3 - 5 } & & Kognitif & Afektif & Psikomotor \\
\hline 1. & AAP & $85 \%$ & $95 \%$ & $70 \%$ \\
2. & AN & $85 \%$ & $80 \%$ & $55 \%$ \\
3. & B & $85 \%$ & $75 \%$ & $50 \%$ \\
4. & H & $85 \%$ & $70 \%$ & $45 \%$ \\
5. & L & $85 \%$ & $85 \%$ & $60 \%$ \\
\hline
\end{tabular}

Berdasarkan data diatas maka dapat ditarik kesimpulan pada saat melakukan post-test didapatkan hasil bahwa aspek yang paling tinggi yaitu aspek kognitif dengan rata-rata skor 17 dan persentase $85 \%$. Sedangkan aspek yang terendah adalah aspek psikomotor dengan skor 11,2 dan persentase $56 \%$.

\section{Analisis Data dan Pengujian Hipotesis}

Data yang telah dihimpun dari pre-test dan post-test kemudian dibandingkan untuk mengetahui apakah terdapat pengaruh aplikasi CODA terhadap pengenalan warna bagi penyandang Tunanetra di kelas VIII MTs LB A Yaketunis. Berikut disajikan table kemampuan awal (pre-test) dan kemampuan akhir (post-test) kelima subjek.

Tabel 5. Perolehan skor pre-test dan post-test kemampuan mengenal warna bagi penyandang Tunanetra kelas VIII MTs LB A Yaketunis.

\begin{tabular}{clcccccr}
\hline \multirow{2}{*}{ No } & \multirow{2}{*}{ Subjek } & \multicolumn{3}{c}{ Pre-test } & \multicolumn{3}{c}{ Post-test } \\
\cline { 3 - 7 } & & Skor Max & Skor perolehan & Presentase & Skor Max & Skor perolehan & Presentase \\
\hline 1. & AAP & 60 & 32 & $53,3 \%$ & 60 & 50 & $83,30 \%$ \\
2. & AN & 60 & 28 & $46,4 \%$ & 60 & 44 & $73,30 \%$ \\
3. & B & 60 & 26 & $43,3 \%$ & 60 & 42 & $70,00 \%$ \\
4. & H & 60 & 24 & $40 \%$ & 60 & 40 & $66,60 \%$ \\
5. & L & 60 & 26 & $43,3 \%$ & 60 & 46 & $76,60 \%$ \\
\multicolumn{1}{l}{ Rerata } & & $\mathbf{2 7 , 2}$ & $\mathbf{4 5 , 3} \%$ & & $\mathbf{4 4 , 4}$ & $\mathbf{7 3 , 9 6 \%}$ \\
\hline
\end{tabular}

Dari data di atas menunjukkan bahwa pada rata-rata pre-test seluruh subjek memiliki rata-rata skor 27,2 \%. Sedangkan setelah mendapatkan perlakuan pengenalan warna menggunakan aplikasi CODA, pada seluruh subjek berada pada skor post-test 44,4. Sehingga dapat diketahui bahwa adanya perubahan pada semua subjek yang lebih baik dengan pencapaian 17,2. Begitu juga pada presentase pre-test, rata-rata sebesar 45,3\% sedangkan pada presentase post-test sebesar 73,96 \% sehingga dapat diketahui adanya rata-rata perubahan pada semua subjek sebesar 28,66 \%. Perubahan pre-test dan post-test kemampuan mengenal warna pada kelima subjek dapat dilihat pada histogram dibawah ini:

\section{Pre-test dan Post-test}

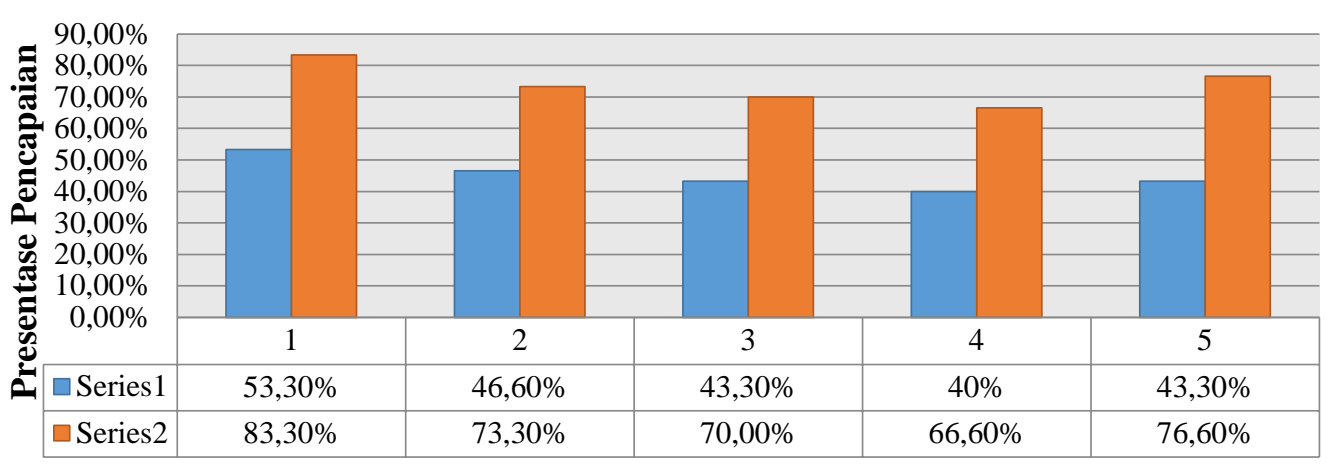

Tabel 4. Histogram perubahan positif kemampuan pengenalan warna bagi penyandang Tunanetra hasil dari data pre-test dan post-test 
Keterangan:

$$
\begin{array}{ll}
1= & \text { adalah subjek AAP } \\
2= & \text { adalah subjek AN } \\
3= & \text { adalah subjek B } \\
4= & \text { adalah subjek H } \\
5= & \text { adalah subjek L }
\end{array}
$$

Data pada histogram dapat menjelaskan bahwasanya pre-test subjek AAP adalah 53,30\% namun setelah mndapat perlakuan kemampuan mengenal warna, maka subjek AAP dapat berubah menjadi 83,30\%. Pada subjek AN juga mengalami perubahan yang lebih baik, terlihat dari presentase pre-test adalah $46,6 \%$ sedangkan hasil post-test $73,3 \%$. Hal ini juga sama terjadi pada B mengalami perubahan yang lebih baik dalam kemampuan mengenal warna yaitu dengan ditunjukkan perubabahan positif dari skor pre-test $43,3 \%$ dan skor post-test 70,0\%. Subjek H juga mengalami perubahan positif yaitu dari skor pre-test 40,0\% kemudian skor post-test 66,6\%. Selain itu, subjek L juga mengalami perubahan positif pada kemampuan mengenal warna yaitu dengan skor pre-test $43,3 \%$ dan skor post-test $76,6 \%$. Berdasarkan data tersebut maka masing-masing subjek mengalami perubahan yang lebih baik dengan AAP mengalami perubahan sebesar $30.0 \%$, AN mengalami perubahan $26,7 \%$, B mengalami perubahan 26,7\%, H mengalami perubahan sebesar 26,6\%, dan L mengalami perubahan sebesar $33,3 \%$.

Setelah diketahui data pre-test dan post-test maka dilanjutkan dengan uji hipotesis untuk mengetahui aplikasi CODA memiliki pengaruh atau tidak terhadap kemampuan mengenal warna bagi penyandang tunanetra. Uji hipotesis yang digunakan adalah tes Wilcoxon. Tahap-tahap uji hipotesis sesuai dengan tahapan Sidney Siegel adalah sebagai berikut:

1. Penentuan Hipotesis Nol

Ha: Ada pengaruh aplikasi Color Detector for Blind Based on Android (CODA) terhadap Pengenalan Warna bagi Penyandang Tunanetra Kelas VIII di MTs LB Yaketunis Yogyakarta.

$H_{0}$ : Tidak ada pengaruh aplikasi Color Detector for Blind Based on Android (CODA) terhadap Pengenalan Warna bagi Penyandang Tunanetra Kelas VIII di MTs LB Yaketunis Yogyakarta.

2. Tes Statistik

Tabel 6. Perubahan skor kemampuan mengenal warna anak tunanetra

\begin{tabular}{llccccc}
\hline No & Subjek & $\begin{array}{c}\text { Skor } \\
\text { pre-test }\end{array}$ & $\begin{array}{c}\text { Skor } \\
\text { post-test }\end{array}$ & $\boldsymbol{d}$ & $\begin{array}{c}\text { Ranking } \\
\boldsymbol{d}\end{array}$ & $\begin{array}{c}\text { Ranking tanda yang lebih } \\
\text { kecil frekuensinya }\end{array}$ \\
\hline 1 & AAP & 32 & 50 & 18 & 4 & 0 \\
2 & AN & 28 & 44 & 16 & 2 & 0 \\
3 & B & 26 & 42 & 16 & 2 & 0 \\
4 & H & 24 & 40 & 16 & 2 & 0 \\
5 & L & 26 & 46 & 20 & 5 & 0 \\
& & & & & $\mathrm{~T}=0$ \\
\hline
\end{tabular}

$T$ hitung $\quad=0$ (jumlah tanda yang lebih kecil frekuensinya)

$N \quad=5$ (Jumlah Subjek)

Pada table IX Robert L. McCormack dalam ( J. Supranto, 2001: 349), terlihat T adalah 0

3. Tingkat SIginifikansi

Tes ini menggunakan taraf signifikansi $1 \%$ atau $\alpha=0,01$

4. Daerah penolakan

Daerah penolakan yang digunakan berupa dua sisi dengan syarat Ho kurang dari atau sama dengan, dan taraf signifikansi 0,01. Ho ditolak apabila $T$ hitung $\leq T$ tabel, $\alpha=0,01$

5. Menarik Keputusan

$T$ table $=0 \quad T$ hitung $=0$

Perhitungan:

$T$ hitung $\leq T$ tabel, $\alpha=0,01$

$0 \leq 0, \alpha=0,01$ 


\section{J PK (J urnal Pendidikan Khusus), 13 (1), 2018 - 42}

Sayidatul Maslahah, Tin Suharmini

Karena hasil yang diperoleh $T$ hitung sama dengan $T$ table sehingga $T$ hitung berada di daerah penolakan Ho dengan taraf signifikansi 0,01 maka dari perhitungan tersebut dapat ditarik keputusan bahwa Ho ditolak dan Ha diterima.

Jadi dapat disimpulkan bahwa ada pengaruh yang sangat signifikan aplikasi CODA terhadap pengenalan warna bagi penyandang tunanetra kelas VIII MTs LB A Yaketunis Yogyakarta.

\section{Pembahasan}

Menurut Daniel P. Hallahan, James M. Kauffman, dan Paige C. Pullen (2009: 380), tunanetra adalah seseorang anak yang memiliki ketajaman visual 20/200 atau kurang pada mata/penglihatan yang lebih baik setelah dilakukan koreksi (misalnya kacamata) atau memiliki bidang penglihatan yang begitu sempit dengan diameter terlebar memiliki jarak sudut pandang tidak lebih dari 20 derajat. Berdasarkan seluruh indera yang dimiliki oleh manusia, penglihatan adalah dria yang paling penting. hal ini dikarenakan dria ini memiliki yang lebih banyak dibandingkan dengan dria-dria yang lain. contohnya daya mengintegrasikan pengamatan lingkungan, daya diskriminasi pengamatan, dan lain sebagainya. bahkan, hubungan dengan lingkungan dan memperoleh informasi, diperkirakan $85 \%$ fungsi indera penglihatan (Rudiyati, 2002: 74).

Pada saat seseorang melakukan sesuatu dengan menggunakan penglihatan, maka akan terjadi kombinasi dari beberapa jenis persepsi visual.Salah satu cara untuk meningkatkan fungsi persepsi visual bagi penyandang Tunanetra adalah persepsi diskriminasi visual (visual discrimination) yaitu pengamatan dimana seseorang dapat membeda-bedakan satu objek dari yang lain di dalam bentuk, ukuran, warna dan sebagainya (Darmaprawira, Sulasmi W.A, 2002: 27).

Salah satu dampak yang ditimbulkan oleh kehilangan dria penglihatan adalah ketidakmampuan dalam menyampaikan menyampaikan lebih jauh informasi ke persepsi di otak. Oleh sebab itu, sebagai gantinya maka penyandang tunanetra harus berusaha menggunakan sisa dria yang lainnya yang masih berfungsi seoerti dria pendengaran, dria tactual, dria penciuman, dan lain sebagainya untuk memperoleh informasi tentang dunia sekitarnya (Rudiyati, 2002: 77).

Salah satu dampak dari tunanetra adalah kesulitan dalam mengenal warna. Hal ini dikarenakan karena terdapat dua unsure yang sangat penting untuk menikmati warna secara sempurna, karena cahaya adalah sumber warna dan mata. Tanpa adanya kedua unsure tersebut sumber warna dan mata adalah aplikasi untuk menangkap warna dari sumbernya (Darmaprawira, Sulasmi W.A. 2002: 27).

Contohnya adalah penyandang tunanetra yang berada di kelas VIII masih mengalami kesulitan dalam mengenal warna. Hal ini menyebabkan anak tunanetra mengalami kesulitan dalam mengidentifikasi warna yang berada di lingkungan sekitarnya. Padahal warna memiliki manfaat yang bisa digunakan dan dimanfaat oleh tunanetra dalam kehidupan sehari-hari contohnya adalah untuk mengenali warna yang terdapat pada seragam atau pakaian, buah-buahan, dan uang.

Pengenalan warna bagi penyandang tunanetra juga harus memperhatikan aspek-aspek taksonomi Bloom yaitu aspek kognitif, afektif, dan psikomotor. (Anderson \& Krathword, 2014). Upaya untuk memaksimalkan dan meningkatkan mengenal warna bagi penyandang tunanetra perlu adanya inovasi pada alat bantu. Salah satunya adalah dengan memanfaatkan teknologi yaitu android. Android memiliki fitur khusus untuk lebih merambah ke semua kalangan. Salah satu fitur yang disematkan pada Android seri Jelly Bean saat ini adalah fitur TalkBack. Aplikasi ini memiliki fitur yang di rancang khusus untuk pengguna android yang memiliki keterbatasan pengelihatan. Fungsi utama aplikasi ini adalah mengucapkan semua yang dilakukan di ponsel android. Aplikasi TalkBack ini, dibuat untuk mempermudah para penderita kelainan penglihatan atau tunanetra agar dapat menggunakan smartphone android yang kebanyakan memiliki layar sentuh (Eko Priyadi, TT).

Adanya aplikasi ini diharapkan penyandang tunanetra akan memiliki persepsi mengenai warna. Karena pentingnya persepsi bagi seseorang dalam mendapatkan informasi. Hal ini juga sesuai dengan pendapat R. Winaryo (2004) menyebutkan bahwa persepsi adalah kesadaran dan pemahaman yang terbentuk (atau dibentuk) melalui penginderaan diri maupun pengalaman diri. Selain itu, dalam mengenal warna juga harus terdapat sensasi cahaya. Hal ini sesuai dengan pendapat dari Sulasmi Darmaprawira (2001: 28) sensasi warna akan terjadi bila ada cahaya. Jika tidak ada cahaya sensasi warna tidak akan timbul, karena sampai saat ini penampilan warna masih tergantung kepada cahaya. Sensasi adalah rasa yang berhubungan dengan indera. Sensasi warna tentunya berhubungan dengan indera mata, karena sifatnya yang visual. Cahaya merangsang retina mata yang menyebabkan sensasi warna. 


\section{J PK (J urnal Pendidikan Khusus), 13 (1), 2018 - 43}

Sayidatul Maslahah, Tin Suharmini

Namun, sensasi yang didapatkan oleh penyandang tunanetra total tidak bisa mendapatkan rangsangan dari indra penglihatannya. Oleh sebab itu, penyandang tunanetra total harus mendapatkan stimulasi yang memanfaatkan dria selain penglihatan. Contohnya adalah Hellen Keller, seorang tokoh wanita yang Tunanetra dan Tunarungu dapat merasakan warna melalui rabaan dan penciumannya. Dia dapat membedakan warna buah-buahan yang dimakannya, warna bunga-bungaan yang dicium dan dipegangnya, bahkan ia dapat menginterpretasikan warna pemandangannya yang pernah dikunjunginya di Amerika Serikat melalui penciuman. Demikian juga bunyi yang tak pernah didengarnya dapat dirasakan melalui getaran-getaran rabaannya. Melalui buku-buku yang dibacanya ia dapat mengorganisasikan indera yang dimilikinya menjadi lengkap: Through an inner law of completeness my thoughts are not permitted to remain colorness, ucapnya (Walter Sargent, 1964: 19 dalam Darmaprawira, Sulasmi W.A. 2002: 27-28).

Kesulitan dalam mengenali warna bagi penyandang tunanetra tersebut dapat diatasi dengan aplikasi Color Detector for Blind (CODA) Based Android. Aplikasi CODA ini juga sudah menyesuaikan dengan kebutuhan pengguna penyandang tunanetra yaitu dengan memperhatikan aspek memanfaatkan dria-non visual yang bisa digunakan oleh penyandang tunanetra. Salah satunya adalah memanfaatkan dria pendengaran dan tactual. Sehingga penyandang tunanetra dapat melakukan orientasi dan moblitas secara mandiri.

Peneliti membuat fitur yang disesuaikan dengan kebiasaan tunanetra ketika memakai layar sentuh, yaitu menyentuh/menekan layar dua kali akan mengaktifkan kamera, menyentuh/ menekan layar yang lama (sekitar 2 detik) akan menutup aplikasi, terdapat fitur talkback, dimana setiap aksi akan keluar suara. Hal ini didasarkan pada publikasi di Okezone kampus, Koran radar Jogja, icampusindonesia.com, www.bago.co.id, jurnal jogja, Web fip.uny.ac.id, dan seminar Pendidikan Luar Biasa mengemukakan bahwasanya pernah ada program PKM-KC (Program Kreatifitas MahasiswaKarsa Cipta) yang diselenggarakan oleh KEMENRISTEK DIKTI untuk mengatasi permasalahan pengenalan warna dengan menggunakan aplikasi Color Detector for Blind Based on Android (CODA) (Maslahah, Sayidatul, dkk. 2017).

Hasil penelitian yang telah dilakukan menggunakan aplikasi Color Detector for Blind Based on Android (CODA) terhadap pengenalan warna anak tunanetra, pada uji hipotesis, disimpulkan bahwasanya aplikasi tersebut memiliki pengaruh yang sangat signifikan terhadap kemampuan pengenalan warna bagi anak tunanetra. Penelitian tersebut melibatkan 5 anak tunanetra di kelas VIII MTs LB A Yaketunis.

Perubahan kemampuan mengenal warna yang lebih baik pada kelima subjek ditunjukkan dengan data hasil penguasaan kemampuan mengenal warna sebelum menggunakan aplikasi Color Detector for Blind Based on Android (CODA) atau skor pre-test dan skor post-test setelah perlakuan terhadap anak tunanetra. Hasil tersebut sesuai dengan penjabaran bahwa subjek AAP awal sebelum mendapatkan perlakuan (pre-test) dengan menggunakan aplikasi Color Detector for Blind Based on Android (CODA). Saat pre-test mendapatkan skor 32 dari skor maksimal 60 atau presentasenya 53,3\%. Kemudian setelah mendapatkan perlakuan dengan Color Detector for Blind Based on Android (CODA) sebanyak 5 kali AAP mendapatkan skor pengenalan warna 50 dari skor maksimal 60 atau presentasenya $83,3 \%$. Perubahan positif yang didapat AAP sebesar 18 skor dengan presentase perubahan $30,0 \%$.

Perubahan kemampuan mengenal warna bagi penyandang tunanetra ini ditunjukkan melaui data pre-test dan post-test. Dari data menunjukkan bahwa pada rata-rata pre-test seluruh subjek memiliki rata-rata skor $27,2 \%$. Sedangkan setelah mendapatkan perlakuan pengenalan warna menggunakan aplikasi CODA, pada seluruh subjek berada pada skor post-test 44,4. Sehingga dapat diketahui bahwa adanya perubahan pada semua subjek yang lebih baik dengan pencapaian 17,2. Begitu juga pada presentase pre-test, rata-rata sebesar 45,3\% sedangkan pada presentase post-test sebesar 73,96 \% sehingga dapat diketahui adanya rata-rata perubahan pada semua subjek sebesar 28,66 \%.

Data pada histogram dapat menjelaskan bahwasanya pre-test subjek AAP adalah 53,30\% namun setelah mndapat perlakuan kemampuan mengenal warna, maka subjek AAP dapat berubah menjadi 83,30\%. Pada subjek AN juga mengalami perubahan yang lebih baik, terlihat dari presentase pre-test adalah 46,6\% sedangkan hasil post-test 73,3\%. Hal ini juga sama terjadi pada B mengalami perubahan yang lebih baik dalam kemampuan mengenal warna yaitu dengan ditunjukkan perubabahan positif dari skor pre-test 43,3\% dan skor post-test 70,0\%. Subjek H juga mengalami perubahan positif yaitu dari skor pre-test 40,0\% kemudian skor post-test 66,6\%. Selain itu, subjek L juga mengalami perubahan 


\section{J PK (J urnal Pendidikan Khusus), 13 (1), 2018 - 44}

Sayidatul Maslahah, Tin Suharmini

positif pada kemampuan mengenal warna yaitu dengan skor pre-test 43,3\% dan skor post-test 76,6\%. Berdasarkan data tersebut maka masing-masing subjek mengalami perubahan yang lebih baik dengan AAP mengalami perubahan sebesar $30.0 \%$, AN mengalami perubahan 26,7\%, B mengalami perubahan 26,7\%, H mengalami perubahan sebesar 26,6\%, dan L mengalami perubahan sebesar $33,3 \%$.

Hasil dari pembahasan peneliti inni, secara keseluruhan, kelima subjek mengalami perubahan kemampuan mengenal warna yang lebih baik karena adanya pengaruh dari aplikasi Color Detector for Blind Based on Android (CODA). Perubahan terjadi setelah adanya perlakuan terhadap kelima subjek AAP, AN, B, H, dan L sebanyak 5 kali. Pada pre-test, kelima subjek rata-rata mendapatkan skor 27,2 dengan presentase $45,3 \%$. Setelah mendapatkan perlakuan dan dilakukan post-test, skor yang diperoleh kelima subjek rata-rata 44,4 dnegan prosentase 73,96\% sehingga rata-rata skor perubahan kelima subjek sebesar 17,2 dengan presentase 28,66\%.

Karena hasil yang diperoleh $T$ hitung sama dengan $T$ table sehingga $T$ hitung berada di daerah penolakan Ho dengan taraf signifikansi 0,01 maka dari perhitungan tersebut dapat ditarik keputusan bahwa Ho ditolak dan Ha diterima. Jadi dapat disimpulkan bahwa ada pengaruh yang sangat signifikan aplikasi CODA terhadap pengenalan warna bagi penyandang tunanetra kelas VIII MTs LB A Yaketunis Yogyakarta.

\section{SIMPULAN}

Berdasarkan hasil analisis data pada penggunaan aplikasi Color Detector for Blind Based on Android (CODA) terhadap kemampuan mengenal warna penyandang tunanetra kelas VIII di MTs LB A Yaketunis Yogyakarta dapat ditarik kesimpulan bahwa ada pengaruh yang sangat signifikan aplikasi Color Detector for Blind Based on Android (CODA) terhadap Pengenalan Warna bagi Penyandang Tunanetra Kelas VIII di MTs LB Yaketunis Yogyakarta. Perolehan skor pre-test menunjukkan kelima subjek rata-rata mendapatkan skor 27,2 dengan presentase 45,3\%. Setelah mendapatkan perlakuan dan dilakukan post-test, skor yang diperoleh kelima subjek rata-rata 44,4 dengan prosentase 73,96\% sehingga rata-rata skor perubahan kelima subjek sebesar 17,2 dengan presentase 28,66\%. Pengaruh penggunaan aplikasi Color Detector for Blind Based on Android (CODA) terhadap Pengenalan Warna bagi Penyandang Tunanetra Kelas VIII di MTs LB Yaketunis Yogyakarta juga dibuktikan dengan melihat hasil uji statistic nonparametric tes Wilcoxon yaitu $T$ hitung $\leq T$ table dengan harga $T$ hitung 0 dan harga $T$ table 0 dengan taraf signifikansi yang digunakan $\alpha=0,01$ maka Ha diterima dan Ho ditolak.

Berdasarkan data dari hasil penelitian maka dapat disimpulkan bahwa semua subjek memiliki skor tertinggi pada aspek kognitif dan skor terendah yang terdapat pada aspek psikomotor.

\section{DAFTAR PUSTAKA}

Anderson, Lorin \& Krathwohl, David. 2014. Kerangka Berpikir Pembelajaran, Pengajaran, dan Asesmen.Yogyakarta: Pustaka Pelajar.

Darmaprawira, Sulasmi. 2002. Warna Teori dan Kreativitas Penggunaannya Edisi Ke-2. Bandung: ITB.

Hallahan, D. P.; Kauffman, J.F; \& Pullen P.C. (2009). Exceptional Learners-Cetakan ke-11. United State: Pearson.

Maslahah, Sayidatul, dkk (2017). Program Kreatifitas Mahasiswa Karsa Cipta. Yogyakarta: UNY \& DIKTI.

Nugroho, Bunafit. (2009). Latihan Membuat Aplikasi Web PHP dan MySQL dengan Dreamweaver $M X(6,7,2004)$ dan 8. Yogyakarta: Gava Aplikasi. 
Nurdian. (2009). Sejarah, Definisi, dan Proses Terjadinya Warna. Diakses dari https://www.scribd.com/doc/14846036/Pertemuan-1-Sejarah-Definisi-Dan-PosesTerjadi-Warna. Pada tanggal 16 April 2016.

Priyadi, Eko. TT. Analisis Aplikasi Talkback bagi Penyandang Tunanetra pada Operasi Sistem Android. Fakultas Teknologi Informatika: Universitas Dian Nuswantoro.

Purwanto, M. Ngalim. (2006). Prinsip-prinsip dan Teknik Evaluasi Pengajaran. Bandung: PT. Remaja Rosda Karya.

Rahmayani, Indah. 2015. Indahnya Raksasa Teknologi Diginal Asia. https://www.kominfo.go.id/content/detail/6095/indonesia-raksasa-teknologi-digitalasia/0/sorotan_media. Diakses tanggal 12 Februari 2018 pukul 11:56 WIB.

Rudiyati, Sari. (2002). Pendidikan Anak Tunanetra. Yogyakarta: Universitas Negeri Yogyakarta.

Siegel, Sidney. (1994). Statistik Non Parametrik untuk Ilmu-ilmu Sosial. Jakarta: PT Graaplikasi.

Soewarno, Bambang, (1997). Metode Kuantitatif dalam Penelitian Ilmu-Ilmu Sosial dan Pendidikan. Jakarta: P2LPTK.

Sugiyono. 2011. Metode Penelitian Kuantitatif Kualitatif dan $R$ \& D. Bandung: Alfabeta.

Winaryo, R. (2004). Self Empowerment Persepsi, Paradigma dan Motivasi Salesman. Jakarta: PT Grasindo. 